\title{
EFFECTS OF OXOTREMORINE ON LOCAL GLUCOSE UTILIZATION IN THE RAT CEREBRAL CORTEX ${ }^{1}$
}

\author{
MAURO DAM, ${ }^{2}$ JAMES K. WAMSLEY, ${ }^{* 3}$ STANLEY I. RAPOPORT, AND EDYTHE D. LONDON ${ }^{4}$ \\ Laboratory of Neurosciences, Gerontology Research Center, National Institute on Aging, Baltimore, Maryland 21224 and \\ *Department of Neuroscience, The Johns Hopkins University School of Medicine, Baltimore, Maryland 21205
}

Received December 10, 1981; Revised March 2, 1982; Accepted March 8, 1982

\begin{abstract}
The $\left[{ }^{14} \mathrm{C}\right] 2$-deoxy-D-glucose technique (Sokoloff, L., M. Reivich, C. Kennedy, M. Des Rosiers, C. Patlak, K. Pettigrew, O. Sakurada, and M. Shinohara (1977) J. Neurochem. 28: 897-916) was used to examine the effects of central muscarinic stimulation on local cerebral glucose utilization (LCGU) in the cerebral cortex of the unanesthetized rat. Systemic administration of the muscarinic agonist oxotremorine (OXO, 0.1 to $1.0 \mathrm{mg} / \mathrm{kg}$, i.p.) increased LCGU in the neocortex, mesocortex, and paleocortex. In the neocortex, OXO was more potent in elevating LCGU of the auditory, frontal, and sensorimotor regions compared with the visual cortex. Within these neocortical regions, OXO effects were greatest in cortical layers IV and V. OXO effects were more dramatic in the neocortex than in the meso- or paleocortex, and no significant effect occurred in the perirhinal and pyriform cortices. OXO-induced LCGU increases were not influenced by methylatropine $(1 \mathrm{mg} / \mathrm{kg}$, s.c.) but were antagonized completely by scopolamine $(2.5 \mathrm{mg} / \mathrm{kg}$, i.p.). Scopolamine reduced LCGU in layer IV of the auditory cortex and in the retrosplenial cortex. The distribution and magnitude of the cortical LCGU response to OXO apparently were related to the distributions of cholinergic neurochemical markers, especially high affinity muscarinic binding sites.
\end{abstract}

The results of electrophysiological, neuroanatomical, chemical, and pharmacological studies have established the role of acetylcholine (Ach) as a neurotransmitter in the mammalian central nervous system. For example, direct electrical stimulation of the cerebral cortex or excitation by transcallosal or peripheral stimulation increases the rate of Ach release from the primary somatosensory cortex of the cat (Mitchell, 1963). Iontophoretic application of Ach activates single cortical cells of cats, rabbits, and monkeys (Krnjević and Phillis, 1961, 1963a, b). Furthermore, pre- and postsynaptic markers for cholinergic synapses (choline acetyltransferase, acetylcholinesterase, Ach, high affinity Ach uptake, and nicotinic and muscarinic cholinergic receptors) have been demonstrated in various regions of the mammalian cerebral

\footnotetext{
${ }^{1}$ We thank H. Holloway, P. Mahone, and A. Ellis for superb technical assistance and P. Ciesla for preparation of the figures. J. K. W. is the recipient of National Institues of Health Postdocloral Fellowship DH05739.

${ }^{2}$ Present address: Clinica delle Malattie Nervose e Mentali, University of Padova, Padova, Italy.

${ }^{3}$ Present address: Department of Psychiatry, College of Medicine, University of Utah, Salt Lake City, UT 84132.

${ }^{4}$ To whom correspondence should be addressed at Laboratory of Neurosciences, National Institute on Aging, Gerontology Research Center, Baltimore City Hospitals, Baltimore, MD 21224.
}

cortex (Yamamura and Snyder, 1974; Salvaterra et al., 1975; Hoover et al., 1978; Uchimura et al., 1978; Emson and Lindvall, 1979; Wamsley et al., 1980, 1981).

The mammalian cerebral cortex is organized in layers which can be differentiated on the basis of cell size and distrubtion (Zeman and Innes, 1963). Iontophoretic evidence indicates that cholinoceptive cells in the cerebral cortex of the cat, rabbit, and monkey are located primarily in deep cortical layers (Krnjević and Phillis, 1963a, b). Neurochemical markers for cholinergic synapses also show a laminar arrangement in the cerebral cortex. For example, high concentrations of acetylcholinesterase occur in layers IV and V of the cat sensorimotor cortex (Beesley and Emson, 1975). Whereas muscarinic cholinergic binding sites are distributed throughout the cerebral cortex, low affinity binding sites are most numerous in layers I, II, III, and IV, and high affinity sites are concentrated in layers IV and Vb (Wamsley et al., 1981; J. K. Wamsley, unpublished observations).

An objective of this study was to determine the distribution in the cerebral cortex of the effects of central muscarinic stimulation in vivo. It also was of interest to compare the distribution of these effects with the known distributions of physiological and chemical markers for cholinergic synapses. Therefore, we studied the in vivo effects of the muscarinic agonist oxotremorine (Cho et 
al., 1962; Lévy and Michel-Ber, 1965) on local cerebral glucose utilization (LCGU) in the rat cerebral cortex. Because the adult brain normally derives almost all of its energy from aerobic glucose oxidation (Sokoloff, 1972), measurements of LCGU should provide information regarding oxidative metabolism and, thereby, local cerebral function.

\section{Materials and Methods}

\section{Materials}

Three-month-old, male, Fischer 344 rats were purchased from Charles River Breeding Laboratories, Wilmington, MA. $\left[{ }^{14} \mathrm{C}\right] 2$-Deoxy-D-glucose $\left(\left[{ }^{14} \mathrm{C}\right] \mathrm{DG}\right.$; specific activity, 55 to $57 \mathrm{mCi} / \mathrm{mmol}$ ) was obtained from New England Nuclear Corp., Boston, MA and was rechromatographed to ascertain purity. Oxotremorine (OXO), methylatropine (atropine methylbromide), and scopolamine hydrobromide were obtained from Sigma Chemical Co., St. Louis, MO.

\section{Preparation of rats}

Under ether anesthesia, rats were prepared with indwelling, femoral venous and arterial catheters as previously described (Sokoloff et al., 1977; Dow-Edwards et al., 1981; London et al., 1981). Following surgery, they were placed in a sound-insulated wooden box $(62 \times 46$ $\times 43 \mathrm{~cm}$ ) where body temperature was regulated with a rectal thermoprobe connected to a feedback device (YSI Indicating Controller model 73ATA; Yellow Springs Instruments, Yellow Springs, $\mathrm{OH}$ ) that activated heating wires on the roof of the box when body temperature fell below $36^{\circ} \mathrm{C}$ (London et al., 1981). The rats were allowed to recover for $4 \mathrm{hr}$ before injection of the drugs or $\left[{ }^{14} \mathrm{C}\right] \mathrm{DG}$. The body temperature of the rats was maintained at 34 to $36^{\circ} \mathrm{C}$ by regulated external heating and was not affected by the drug treatments.

\section{Drug treatments}

Conscious rats were placed in seven treatment groups.

Group 1: Control. Control rats received isotonic saline, $0.9 \%(\mathrm{w} / \mathrm{v}) \mathrm{NaCl}(1 \mathrm{ml} / \mathrm{kg}$ of body weight, s.c., $22 \mathrm{~min}$ before $\left[{ }^{14} \mathrm{C}\right] \mathrm{DG}$ and, i.p., 2 min before $\left.\left[{ }^{14} \mathrm{C}\right] \mathrm{DG}\right)$.

Groups 2, 3, and 4: Oxotremorine-treated rats. OXO rats received atropine methylbromide $(1 \mathrm{mg} / \mathrm{kg}$, s.c., 22 min before $\left.\left[{ }^{14} \mathrm{C}\right] D G\right)$ and OXO $(0.1,0.7$, or $1.0 \mathrm{mg} / \mathrm{kg}$, i.p., $2 \mathrm{~min}$ before $\left.\left[{ }^{14} \mathrm{C}\right] \mathrm{DG}\right)$. The purpose of the atropine methylbromide pretreatment was to block the peripheral muscarinic effects of OXO. This dose of atropine methylbromide blocks lacrimation and diarrhea, but not tremor, in 3-month-old Fisher 344 rats treated with 0.7 $\mathrm{mg} / \mathrm{kg}$ of OXO (Dow-Edwards et al., 1981).

Group 5: Methylatropine-treated rats. Methylatropine rats received atropine methylbromide $(1 \mathrm{mg} / \mathrm{kg}$, s.c., 22 min before $\left.\left[{ }^{14} \mathrm{C}\right] \mathrm{DG}\right)$ and saline $(1 \mathrm{ml} / \mathrm{kg}$, i.p., $2 \mathrm{~min}$ before $\left.\left[{ }^{14} \mathrm{C}\right] \mathrm{DG}\right)$ in order to test the effect of methylatropine alone.

Group 6: Scopolamine plus oxotremorine-treated rats. Scopolamine plus OXO rats received scopolamine hydrobromide $\left(2.5 \mathrm{mg} / \mathrm{kg}\right.$, i.p., $12 \mathrm{~min}$ before $\left.\left[{ }^{14} \mathrm{C}\right] \mathrm{DG}\right)$ and OXO $\left(0.7 \mathrm{mg} / \mathrm{kg}\right.$, i.p., 2 min before $\left.\left[{ }^{14} \mathrm{C}\right] \mathrm{DG}\right)$. The purpose of this treatment regimen was to determine if possible effects of OXO on LCGU could be blocked by central muscarinic antagonism.

Group 7: Scopolamine-treated rats. Scopolamine rats received scopolamine hydrobromide $(2.5 \mathrm{mg} / \mathrm{kg}$, i.p., 12 min before $\left.\left[{ }^{14} \mathrm{C}\right] \mathrm{DG}\right)$ and saline $(1 \mathrm{ml} / \mathrm{kg}$, i.p., $2 \mathrm{~min}$ before $\left.\left[{ }^{14} \mathrm{C}\right] \mathrm{DG}\right)$ in order to test the effects of scopolamine alone.

\section{Measurement of LCGU}

LCGU in various regions of the cerebral cortex was determined in rats after injection of $\left[{ }^{14} \mathrm{C}\right] \mathrm{DG}(125 \mu \mathrm{Ci} / \mathrm{kg}$ of body weight, i.v.) as previously described (Sokoloff et al., 1977; Dow-Edwards et al., 1981). Rats were killed by a pentobarbital overdose $(60 \mathrm{mg}$ in $1 \mathrm{ml}$, i.v.) $50 \mathrm{~min}$ after injection of $\left[{ }^{14} \mathrm{C}\right] \mathrm{DG}$. Brains were removed and frozen in 2-methylbutane (Fisher Scientific Co., Silver Spring, $\mathrm{MD})$ cooled to $-60^{\circ} \mathrm{C}$. Frozen, $20-\mu \mathrm{m}$ sections were obtained by cutting the brains on a Cryo-Cut II cryostat (American Optical Co., Buffalo, NY) maintained at -20 to $-22^{\circ} \mathrm{C}$. Sections were picked up on glass coverslips, and radioactivity in cortical regions was determined by quantitative autoradiography (Sokoloff et al., 1977). Adjacent sections were stained with cresyl violet and examined under a standard Zeiss (West Germany) light microscope so that the layers of the cerebral cortex could be identified. Cortical layers were designated according to Krieg (1946a, b).

LCGU was calculated from brain and plasma radioactivities and plasma glucose concentrations using rate and lumped constants for transport and phosphorylation of $\left[{ }^{14} \mathrm{C}\right] D G$ as given by Sokoloff et al. (1977). Calculations were made with an operational equation that allows the arterial plasma glucose concentration to vary during the experimental period (Sokoloff, 1979).

\section{Statistical analyses}

Statistical significance of differences between drugtreated and control groups was assessed by a one-way analysis of variance and Dunnett's test (Dunnett, 1955; Steel and Torrie, 1960). The criterion for all significance statements was $p<0.05$.

\section{Results}

All doses of OXO produced tremor within $2 \mathrm{~min}$. Tremor following the lowest dose of OXO $(0.1 \mathrm{mg} / \mathrm{kg})$ was slight and was not detectable $25 \mathrm{~min}$ after administration. With increasing doses of $\mathrm{OXO}$, tremor was severe and lasted throughout the experimental period. Scopolamine pretreatment blocked tremor and the peripheral effects of $\mathrm{OXO}$, such as lacrimation and diarrhea. In contrast, methylatropine prevented the peripheral muscarinic effects but not tremor.

OXO-induced increases in LCGU in regions and layers of the cerebral cortex were dose related (Table 1; Fig. 1). At $0.1 \mathrm{mg} / \mathrm{kg}$ of $\mathrm{OXO}$, the only statistically significant effect was a $20 \%$ increase of LCGU in layer IV of the frontal cortex (area 10, according to Krieg, 1946a, b). LCGU was increased significantly by 24 to $38 \%$ in layers IV and $\mathrm{V}$ but not in layers I to III of the auditory (area 41, according to Krieg, 1946a, b), frontal, and sensorimotor (areas 3, 1, and 2, according to Krieg, 1946a, b) 
TABLE I

Glucose utilization in rat cerebral cortex

\begin{tabular}{|c|c|c|c|c|}
\hline \multirow[b]{2}{*}{ Cortical Region } & \multicolumn{4}{|c|}{ Local Cerebral Glucose Utilization after Treatment ${ }^{a}$} \\
\hline & $\begin{array}{l}\text { Control } \\
\text { (9) }\end{array}$ & $\begin{array}{c}\text { Oxotremorine, } 0.1 \mathrm{mg} / \mathrm{kg}+ \\
\text { Methylatropine (5) }\end{array}$ & $\begin{array}{c}\text { Oxotremorine, } 0.7 \mathrm{mg} / \mathrm{kg}+ \\
\text { Methylatropine (9) }\end{array}$ & $\begin{array}{c}\text { Oxotremorine, } 1 \mathrm{mg} / \mathrm{kg}+ \\
\text { Methylatropine (4) }\end{array}$ \\
\hline & \multicolumn{4}{|c|}{$\mu \mathrm{mol} / 100 \mathrm{gm} / \mathrm{min}$} \\
\hline \multicolumn{5}{|l|}{ Neocortex } \\
\hline Auditory & & & & \\
\hline Layers I-III & $91 \pm 5^{b}$ & $96 \pm 5$ & $99 \pm 4$ & $122 \pm 7^{c}$ \\
\hline Layer IV & $111 \pm 7$ & $125 \pm 5$ & $138 \pm 6^{c}$ & $155 \pm 7^{c}$ \\
\hline Layer $\mathrm{Vb}$ & $84 \pm 6$ & $96 \pm 3$ & $113 \pm 3^{\mathrm{c}}$ & $125 \pm 7^{c}$ \\
\hline \multicolumn{5}{|l|}{ Visual } \\
\hline Layer I-III & $80 \pm 6$ & $80 \pm 4$ & $79 \pm 6$ & $96 \pm 8$ \\
\hline Layer IV & $92 \pm 6$ & $100 \pm 7$ & $105 \pm 5$ & $141 \pm 13^{r}$ \\
\hline Layer $\mathrm{Vb}$ & $70 \pm 4$ & $78 \pm 4$ & $85 \pm 5$ & $110 \pm 8^{c}$ \\
\hline \multicolumn{5}{|l|}{ Frontal } \\
\hline Layers I-III & $69 \pm 4$ & $70 \pm 2$ & $80 \pm 4$ & $87 \pm 4^{c}$ \\
\hline Layer IV & $84 \pm 4$ & $101 \pm 2^{c}$ & $111 \pm 5^{c}$ & $141 \pm 6^{\mathrm{c}}$ \\
\hline Layer Vb & $69 \pm 4$ & $73 \pm 4$ & $86 \pm 3^{c}$ & $101 \pm 4^{c}$ \\
\hline \multicolumn{5}{|l|}{ Sensorimotor } \\
\hline Layers I-III & $70 \pm 3$ & $67 \pm 2$ & $80 \pm 4$ & $86 \pm 5$ \\
\hline Layer IV & $88 \pm 4$ & $113 \pm 8$ & $121 \pm 6^{c}$ & $131 \pm 4^{c}$ \\
\hline Layer $\mathrm{Vb}$ & $70 \pm 4$ & $89 \pm 9$ & $94 \pm 4^{c}$ & $109 \pm 3^{c}$ \\
\hline \multicolumn{5}{|l|}{ Mesocortex } \\
\hline \multicolumn{5}{|l|}{ Precentral medial } \\
\hline Superficial layer & $78 \pm 5$ & $85 \pm 4$ & $79 \pm 4$ & $97 \pm 6$ \\
\hline Deep layers & $90 \pm 6$ & $109 \pm 10$ & $108 \pm 4$ & $119 \pm 5^{c}$ \\
\hline \multicolumn{5}{|l|}{ Retrosplenial medial } \\
\hline Superficial layer & $86 \pm 4$ & $98 \pm 9$ & $105 \pm 7$ & $119 \pm 9^{c}$ \\
\hline Deep layers & $72 \pm 5$ & $83 \pm 7$ & $84 \pm 4$ & $100 \pm 3^{c}$ \\
\hline \multicolumn{5}{|l|}{ Paleocortex } \\
\hline Fntorhinal & $52 \pm 4$ & $60 \pm 4$ & $57 \pm 5$ & $68 \pm 2^{c}$ \\
\hline Perirhinal & $53 \pm 4$ & $54 \pm 1$ & $52 \pm 3$ & $64 \pm 3$ \\
\hline Pyriform & $55 \pm 5$ & $51 \pm 3$ & $49 \pm 2$ & $58 \pm 3$ \\
\hline
\end{tabular}

"See "Materials and Methods" for details regarding the treatment regimens. The number of animals included in each group is indicated in parentheses.

${ }^{h}$ Means \pm SEM.

'Significant difference from control, $p<0.05$.

cortices by $0.7 \mathrm{mg} / \mathrm{kg}$ of OXO. LCGU in the visual cortex (areas 17 and 18, according to Krieg, 1946a, b) was not increased significantly (14 to $20 \%$ increase in layers IV and V). No effects of this dose of OXO were noted in regions of the medial or paleocortex. However, $1 \mathrm{mg} / \mathrm{kg}$ of OXO significantly increased LCGU by 26 to $68 \%$ in all portions of the neocortex except layers I to III of the visual and sensorimotor cortices. As with the lower doses, the greatest increase was in the frontal cortex. The highest dose of OXO $(1.0 \mathrm{mg} / \mathrm{kg})$ also increased LCGU by 24 to $38 \%$ in the medial cortex. Significant increases (30 to 38\%) occurred in the deep layers of the precentral medial cortex and in superficial and deep layers of the retrossplenial medial cortex. This dose of OXO also increased LCGU by $31 \%$ in the entorhinal cortex but not in the perirhinal or pyriform cortices.

In all OXO-treated rats, columns of increased LCGU, oriented perpendicular to the surface, were apparent in the neocortex. These are shown in the rostral auditory and parietal cortices (Fig. 2). Similar columns frequently were observed in the sensorimotor cortex; however, this was not as consistent a finding. A columnar arrangement of LCGU in the auditory cortex was observed occasionally in control rats but never in rats treated with scopolamine or with scopolamine plus OXO. In OXO-treated rats, columns of LCGU became more distinct with increasing doses of $\mathrm{OXO}$.

Whereas methylatropine alone did not alter LCGU in any of the 19 brain regions assayed, scopolamine reduced LCGU by 26 to $32 \%$ in layer IV of the auditory cortex and in superficial and deep layers of the retrosplenial medial cortex (Table II). Prior treatment with scopolamine also completely antagonized the OXO-induced increases in LCGU.

\section{Discussion}

Systemic treatment with OXO increases LCGU, in a dose-related manner, in the rat cerebral cortex. OXOinduced increases in LCGU result from central muscarinic stimulation because they are blocked completely by scopolamine, a centrally acting antimuscarinic agent (Innes and Nickerson, 1971) but not by methylatropine which antagonizes peripheral OXO effects.

Scopolamine not only completely blocks OXO-induced 

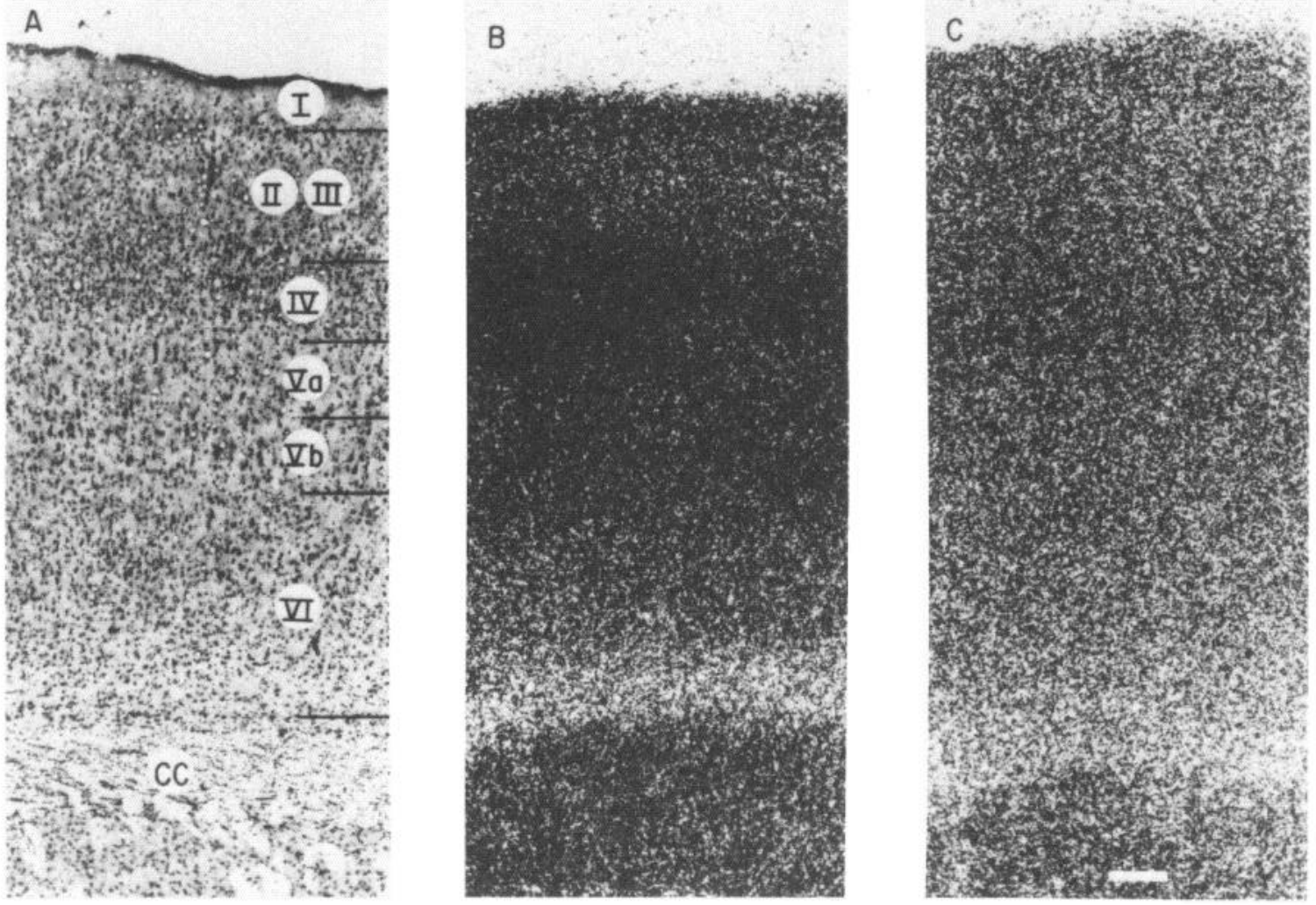

Figure 1. Laminar arrangement of cells and autoradiographic grain densities, representing glucose utilization, in the rostral parietal cortex. Photomicrographs $B$ and $C$ show the autoradiographic grain distribution on x-ray film exposed to 20 - $\mu \mathrm{m}$ brain sections from rats subjected to the $\left[{ }^{14} \mathrm{C}\right] \mathrm{DG}$ procedure. $A$, Photomicrograph of a tissue section stained with cresyl violet. The Roman numerals indicate the approximate borders of the laminae of the cerebral cortex. The corpus callosum $(C C)$ also can be seen. $B$, Autoradiogram depicting the grain density in the cerebral cortex of a rat injected with methylatropine ( $1 \mathrm{mg} / \mathrm{kg}$, $\mathrm{s.c}$., 22 min before $\left.\left[{ }^{14} \mathrm{C}\right] \mathrm{DG}\right)$ and $\mathrm{OXO}\left(0.7 \mathrm{mg} / \mathrm{kg}\right.$, i.p., 2 min before $\left.\left[{ }^{14} \mathrm{C}\right] \mathrm{DG}\right)$. $C$, Autoradiogram showing the grain density associated with a section of cerebral cortex from a control rat. Note that $B$ shows an overall increase in LCGU in the cerebral cortex over that shown in $C$. However, statistically significant increases are seen (at this concentration of OXO) only in layers IV and Vb. Bar, $200 \mu \mathrm{m}$.

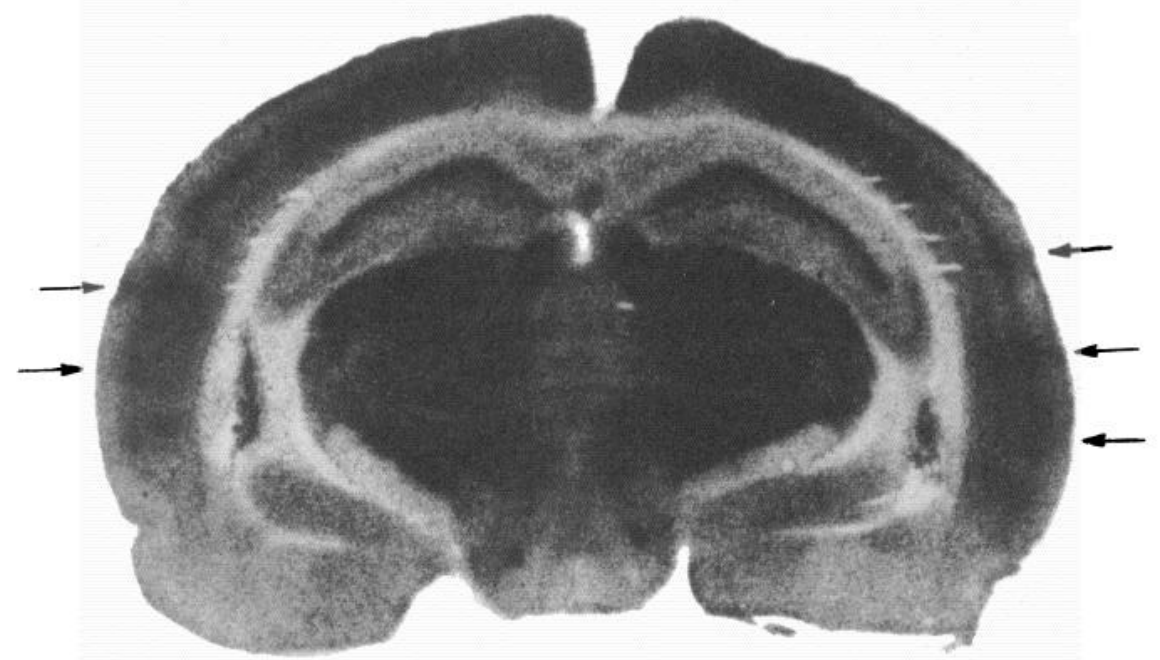

Figure 2. Columnar pattern of autoradiographic grain densities, representing glucose utilization, in the rostral auditory and parietal cortices. This is a photograph of $x$-ray film exposed to $20-\mu \mathrm{m}$ brain sections from a rat injected with methylatropine $(1 \mathrm{mg} / \mathrm{kg}, \mathrm{s.c} ., 22$ min before $\left.\left[{ }^{14} \mathrm{C}\right] \mathrm{DG}\right)$ and oxotremorine $\left(1 \mathrm{mg} / \mathrm{kg}\right.$, i.p., $2 \mathrm{~min}$ before $\left.\left[{ }^{14} \mathrm{C}\right] \mathrm{DG}\right)$. Columns of high grain density are indicated by arrows. 
TABLE II

Glucose utilization in rat cerebral cortex

\begin{tabular}{|c|c|c|c|c|c|}
\hline \multirow{2}{*}{ Cortical Region } & \multicolumn{5}{|c|}{ Local Cerebral Glucose Utilization after Treatment ${ }^{a}$} \\
\hline & Control (9) & Methylatropine (7) & $\begin{array}{l}\text { Oxotremorine, } 0.7 \mathrm{mg} / \mathrm{kg} \\
\text { + Methylatropine }(9)\end{array}$ & Scopolamine (9) & $\begin{array}{l}\text { Scopolamine + Oxo- } \\
\text { tremorine (4) }\end{array}$ \\
\hline & \multicolumn{5}{|c|}{$\mu \mathrm{mol} / 100 \mathrm{gm} / \mathrm{min}$} \\
\hline \multicolumn{6}{|l|}{ Neocortex } \\
\hline \multicolumn{6}{|l|}{ Auditory } \\
\hline Layers I-III & $91 \pm 5^{b}$ & $99 \pm 3$ & $99 \pm 4$ & $76 \pm 5$ & $88 \pm 3$ \\
\hline Layer IV & $111 \pm 7$ & $111 \pm 8$ & $138 \pm 6^{r}$ & $76 \pm 7^{c}$ & $89 \pm 5$ \\
\hline Layer $\mathrm{Vb}$ & $84 \pm 6$ & $84 \pm 4$ & $113 \pm 3^{c}$ & $71 \pm 7$ & $77 \pm 2$ \\
\hline \multicolumn{6}{|l|}{ Visual } \\
\hline Layers I-III & $80 \pm 6$ & $86 \pm 3$ & $79 \pm 6$ & $75 \pm 4$ & $77 \pm 9$ \\
\hline Layer IV & $92 \pm 6$ & $90 \pm 5$ & $105 \pm 5$ & $78 \pm 6$ & $87 \pm 10$ \\
\hline Layer $\mathrm{Vb}$ & $70 \pm 4$ & $74 \pm 4$ & $85 \pm 5$ & $71 \pm 6$ & $73 \pm 6$ \\
\hline \multicolumn{6}{|l|}{ Frontal } \\
\hline Layers I-III & $69 \pm 4$ & $72 \pm 4$ & $80 \pm 4$ & $68 \pm 4$ & $71 \pm 3$ \\
\hline Layer IV & $84 \pm 4$ & $86 \pm 6$ & $111 \pm 5^{c}$ & $69 \pm 5$ & $80 \pm 8$ \\
\hline Layer $\mathrm{Vb}$ & $69 \pm 4$ & $68 \pm 4$ & $86 \pm 3^{c}$ & $63 \pm 4$ & $74 \pm 3$ \\
\hline \multicolumn{6}{|l|}{ Sensorimotor } \\
\hline Layers I-III & $70 \pm 3$ & $73 \pm 5$ & $80 \pm 4$ & $78 \pm 6$ & $72 \pm 5$ \\
\hline Layer IV & $88 \pm 4$ & $90 \pm 5$ & $121 \pm 6^{c}$ & $75 \pm 4$ & $86 \pm 3$ \\
\hline Layer $\mathrm{Vb}$ & $70 \pm 4$ & $69 \pm 4$ & $94 \pm 4^{c}$ & $71 \pm 5$ & $74 \pm 1$ \\
\hline \multicolumn{6}{|l|}{ Mesocortex } \\
\hline \multicolumn{6}{|l|}{ Precentral medial } \\
\hline Supcrficial layer & $78 \pm 5$ & $72 \pm 3$ & $79 \pm 1$ & $64 \pm 1$ & $74 \pm 3$ \\
\hline Deep layers & $90 \pm 6$ & $75 \pm 4$ & $108 \pm 4$ & $72 \pm 5$ & $82 \pm 9$ \\
\hline \multicolumn{6}{|l|}{ Retrosplenial medial } \\
\hline Superficial layer & $86 \pm 4$ & $80 \pm 6$ & $105 \pm 7$ & $59 \pm 4^{c}$ & $68 \pm 3^{c}$ \\
\hline Deep layers & $72 \pm 5$ & $71 \pm 6$ & $84 \pm 4$ & $53 \pm 4^{c}$ & $60 \pm 2$ \\
\hline \multicolumn{6}{|l|}{ Paleocortex } \\
\hline Entorhinal & $52 \pm 4$ & $50 \pm 4$ & $57 \pm 5$ & $50 \pm 4$ & $56 \pm 2$ \\
\hline Perirhinal & $53 \pm 4$ & $51 \pm 2$ & $52 \pm 3$ & $46 \pm 3$ & $52 \pm 3$ \\
\hline Pyriform & $55 \pm 5$ & $50 \pm 3$ & $49 \pm 2$ & $44 \pm 4$ & $47 \pm 3$ \\
\hline
\end{tabular}

"See "Materials and Methods" for details regarding the treatment regimens. The number of animals included in each group is indicated in parentheses.

"Means \pm SEM.

"Significant difference from control, $p<0.05$.

increases in LCGU but also significantly reduces LCGU in layer IV of the auditory cortex and in superficial and deep layers of the retrosplenial medial cortex. This agrees with a previous report that scopolamine significantly decreases LCGU in the cerebral cortex of the Wistar rat (Weinberger et al., 1979). This effect on cortical LCGU may be related to scopolamine's action to induce amnesia in man as well as rats (Drachman and Leavitt, 1974; Moss et al., 1981). However, the influence of scopolamine on recent memory may involve extracortical brain regions. In this regard, we have noted recently that scopolamine markedly decreases LCGU in the anterior thalamus (Dam et al., 1981).

The effects of OXO to increase LCGU in the auditory and sensorimotor cortices occur in vertical columns. Columnar patterns of increased LCGU in rats have been noted in the parietal cortex after spreading cortical depression (Shinohara et al., 1979) and in the somatosensory cortex after vibrissal stimulation (Hand, 1982). Lorente de Nó (1938) predicted a columnar organization of the cerebral cortex based on anatomical data. This arrangement has been confirmed in the sensorimotor and visual cortices of the cat and rat (Mountcastle, 1957;
Hubel and Wiesel, 1962; Armstrong-James, 1975; Axelrad et al., 1976). Abeles and Goldstein (1970) reported that columns were not clearly demonstrable by physiological techniques in the cat auditory cortex. However, the current findings indicate that functional columns indeed exist in the mammalian auditory cortex.

In addition to the columnar arrangement of OXOinduced increases in cortical LCGU, the LCGU response to $\mathrm{OXO}$ in the rat neocortex shows a laminar distribution. Whereas no significant $O X O$ effects are seen in layers I to III, $0.7 \mathrm{mg} / \mathrm{kg}$ of OXO increases LCGU by up to $38 \%$ in layers IV and $\mathrm{Vb}$. The effects of OXO in layers I to III are significant only with the highest dose tested $(1 \mathrm{mg} /$ $\mathrm{kg}$ ).

The response to OXO in layers IV and V coincides with the laminar distribution of cholinoceptive cells (Krnjević and Phillis, 1963a, b), the concentration of acetylcholinesterase (Beesley and Emson, 1975), and the densities of high affinity muscarinic binding sites in the neocortex (Wamsley et al., 1981; J. K. Wamsley, unpublished data). Furthermore, to our knowledge, this is the first report of a functional subdivision of layer $V$.

The positive correlation between the densities of high 
affinity muscarinic binding sites and the LCGU response to OXO suggests that high affinity muscarinic binding sites are functionally important. This apparently is not true in smooth muscle, where the low affinity binding sites seem to be the ones concerned with contractile responses (Birdsall et al., 1978). Similarly, in a neuroblastoma clone, it appears that the low affinity sites mediate guanylate cyclase activation (Strange et al., 1977).

However, the LCGU response to systemic drug treatments depends not only on the presence of relevant receptors but also on afferents to the brain region studied (Dow-Edwards et al., 1981; Palacios et al., 1981). In this regard, the neocortex receives inputs from various thalamic nuclei. For example, specific thalamic nuclei project to layers III and IV, whereas fibers from the intralaminar nuclei project to layer V (Lorente de Nó, 1938; Herkenham, 1980). It is possible that these thalamic regions also are affected by OXO and that some LCGU effects of OXO in the neocortex are secondary to thalamic stimulation by OXO.

At $0.7 \mathrm{mg} / \mathrm{kg}$, OXO stimulates LCGU in the auditory, frontal, and sensorimotor, but not visual, cortices. One milligram per $\mathrm{kg}$ of $\mathrm{OXO}$ increases LCGU in the visual cortex; however, at this dose, the tendency is for enhanced LCGU in all cortical layers. The reason for the relatively low potency of $\mathrm{OXO}$ in the visual cortex is not known. LCGU is increased in the meso- and paleocortices with this high dose of OXO but not with lower doses. A possible explanation for the greater potency of OXO in regions of the neocortex is the more developed laminar arrangement in these regions as compared with the mesoand paleocortices. Furthermore, whereas the proportion of ACh-sensitive cells in the pyriform cortex is similar to that reported for neocortical cells (Legge et al., 1966; Krnjević and Phillis, 1963a, b; Randić et al., 1964), paleocortical cholinoceptive cells are distributed fairly uniformly throughout all layers, not concentrated in the deeper layers (Legge et al., 1966).

The OXO-induced increase in LCGU in cortical layers IV and $V$ of the neocortex may have therapeutic relevance for human Alzheimer's disease. Evidence suggests that the major cholinergic projection to the neocortex terminates in these deep layers (Krnjević and Silver, 1965). In Alzheimer's disease, there is a profound loss of recent memory (Alzheimer, 1907) and in neocortical choline acetyltransferase (Davies and Maloney, 1976; Perry et al., 1977; White et al., 1977; Davies, 1979), acetylcholinesterase (Op den Velde and Stam, 1976), and high affinity choline uptake (Bowen and Davison, 1978). In contrast, the cholinergic muscarinic receptor in the cortex remains relatively unaffected (Davies and Verth, 1978). This suggests that, while the projection to layers IV and V degenerates, local function in the deep cortical layers may be enhanced by direct receptor agonists.

\section{References}

Abeles, M., and M. H. Goldstein, Jr. (1970) Functional architecture in cat visual and auditory cortex: Cellular organization according to depth. J. Neurophysiol. 33: 172-187.

Alzheimer, A. (1907) İher eine eigenartige Frkrankung der Hirnrinde. Allg. Z. Psychiat. 64: 146-148.

Armstrong-James, M. (1975) The functional status and colum- nar organization of single cells responding to cutaneous stimulation of neonatal rat somatosensory cortex SI. J. Physiol. (Lond.) 246: 501-538.

Axelrad, H., R. Verley, and E. Farkas (1976) Responses evoked in mouse and rat SI cortex by vibrissal stimulation. Neurosei. Lett. 3: 265-274.

Beesley, P. W., and P. C. Emson (1975) Distribution of transmitter related enzymes in the rat sensorimotor cortex. Biochem. Soc. Trans. 3: 936-939.

Birdsall, N. J. M., A. S. V. Burgen, and E. C. Hulme (1978) The binding of agonists to brain muscarinic receptors. Mol. Pharmacol. 14: 723-736.

Bowen, D. M., and A. M. Davison (1978) Changes in brain lysosomal activity neurotransmitters, related enzymes and other proteins in senile dementia. In Alzheimer's Disease, Senile Dementia and Related Disorders, R. Katzman, R. D. Terry, and K. L. Bick, eds., pp. 421-424, Raven Press, New York.

Cho, A. K., W. L. Haslett, and D. L. Jenden (1962) The peripheral actions of oxotremorine, a metabolite of tremorine. J. Pharmacol. Exp. Ther. 138: 249-257.

Dam, M., H. Holloway, P. Mahone, D. Dow-Edwards, and E. London (1981) Oxotremorine increases glucose utilization in the Papez circuit. Trans. Am. Soc. Neurochem. 12: 220.

Davies, P. (1979) Neurotransmitter-related enzymes in senile dementia of the Alzheimer type. Brain Res. 171: 319-327.

Davies, P. G., and A. J. F. Maloney (1976) Selective loss of central cholinergic neurons in Alzheimer's disease. Lancet 2: 1403.

Davies P., and A. H. Verth (1978) Regional distribution of muscarinic acetylcholine receptors in normal and Alzheimer's type dementia brains. Brain Res. 138: 385-392.

Dow-Edwards, D. L., M. Dam, J. M. Peterson, S. I. Rapoport, and E. D. London (1981) Effect of oxotremorine on local cerebral glucose utilization in motor system regions of the rat brain. Brain Res. 266: 281-289.

Drachman, D. A., and J. Leavitt (1974) Human memory and the cholinergic system. Arch. Neurol. 30: 113-121.

Dunnett, C. (1955) A multiple comparison procedure for comparing several treatments with a control. J. Am. Statist. Assn. 50: 1096-1121.

Emson, P. C., and O. Lindvall (1979) Distribution of putative neurotransmitters in the neocortex. Neuroscience 4: 1-30.

Hand, P. J. (1982) Plasticity of the rat cortical barrel system. In Changing Concepts of the Nervous System, A. R. Morrison and P. L. Strids, eds., pp. 49-68, Academic Press, New York.

Herkenham, M. (1980) Laminar organization of thalamic projections to the rat neocortex. Science 207: 532-535.

Hoover, D. B., E. A. Muth, and D. M. Jacobowitz (1978) A mapping of the distribution of acetylcholine, choline acetyltransferse in discrete areas of rat brain. Brain Res. 153: 295-306.

Hubel, D. H., and T. N. Wiesel (1962) Receptive fields, binocular interaction and functional architecture in the cat's visual cortex. J. Physiol. (Lond.) 160: 106-154.

Innes, I. R., and M. Nickerson (1971) Drugs inhibiting the action of acetylcholine on structures innervated by postganglionic parasympathetic nerves (antimuscarinic or atropinic drugs). In The Pharmacological Basic of Therapeutics, L. S. Goodman and A. Gilman, eds., pp. 524-528, Macmillan Co., New York.

Krieg, W. J. S. (1946a) Connections of the cerebral cortex. I. The albino rat. A. Topography of the cortical areas. J. Comp. Neurol. 84: 221-275.

Krieg, W. J. S. (1946b) Connections of the cerebral cortex. I. The albino rat. B. Structure of the cortical areas. J. Comp. Neurol. 84: 277-323.

Krnjević, K., and J. W. Phillis (1961) Sensitivity of cortical neurons to acetylcholine. Experientia 17: 469. 
Krnjević, K., and J. W. Phillis (1963a) Ionophoretic studies of neurons in the mammalian cerebral cortex. J. Physiol. (Lond.) 165: 274-304.

Krnjević, K., and J. W. Phillis (1963b) Acetylcholine-sensitive cells in the cerebral cortex. J. Physiol. (Lond.) 166: 296-327.

Krnjević, K., and A. Silver (1965) A histochemical study of cholinergic fibers in the cerebral cortex. J. Anat. 99: 711-759.

Legge, K. F., M. Randić, and D. W. Straughan (1966) The pharmacology of neurons in the pyriform cortex. Br. J. Pharmacol. 26: 87-107.

Lévy, J., and E. Michel-Ber (1965) Sur le metabolite de la tremorine, l'oxotremorine. Therapie 20: 265-267.

London, E. D., S. M. Nespor, M. Ohata, and S. I. Rapoport (1981) Local cerebral glucose utilization during development and aging of the Fischer-344 rat. J. Neurochem. 37: 217-221.

Lorente de Nó, R. (1938) Cerebral cortex: Architecture, intracortical connections, motor projections. In Physiology of the Nervous System, J. F. Fulton, ed., Ed. 2, pp. 274-313, Oxford University Press, New York.

Mitchell, J. F. (1963) The spontaneous and evoked release of acetylcholine from the cerebral cortex. J. Physiol. (Lond.) 165: $98-116$.

Moss, D. E., J. B. Rogers, J. A. Deutsch, and R. R. Salome (1981) Time dependent changes in anterograde scopolamineinduced amnesia in rats. Pharmacol. Biochem. Behav. 14: 321-323.

Mountcastle, V. B. (1957) Modality and topographic properties of single neurons of cat's somatic sensory cortex. J. Neurophysiol. 20: 408-434.

Op den Velde, W., and F. C. Stam (1976) Some central proteins in enzyme systems in Alzheimer's presenile and senile dementia. J. Am. Geriatr. Soc. 24: 12-16.

Palacios, J. M., M. J. Kuhar, S. I. Rapoport, and E. D. London (1981) Increases and decreases in local cerebral glucose utilization in response to GABA agonists. Eur. J. Pharmacol. 71: 333-336.

Perry, E. K., R. H. Perry, G. Blessed, and B. E. Tomlinson (1977) Necropsy evidence of central cholinergic deficit in senile dementia. Lancet $1: 189$.

Randić, M., R. Siminoff, and D. W. Straughan (1964) Acetylcholine depression of cortical neurons. Exp. Neurol. 9: 236-242.

Salvaterra, P. M., H. R. Mahler, and W. J. Moore (1975) Subcellular and regional distribution of ${ }^{125} \mathrm{I}$-labelled $\alpha$-bungarotoxin binding in rat brain and its relationship to acetylcholinesterase and choline acetyltransferase. J. Biol. Chem. 250: $6469-6475$.
Shinohara, M., B. Dollinger, G. Brown, S. Rapoport, and L. Sokoloff (1979) Cerebral glucose utilization: Local changes during and after recovery from spreading cortical depression. Science 203: 188-190.

Sokoloff, L. (1972) Circulation and energy metabolism of the brain. In Basic Neurochemistry, G. J. Siegel, R. W. Albers, R. Katzman, and B. W. Agranoff, eds., Ed. 2, pp. 388-413, Little, Brown and Co., Boston.

Sokoloff, L. (1979) The $\left[{ }^{14} \mathrm{C}\right]$ deoxyglucose method: Four years later. Acta Neurol. Scand. (Suppl. 72) 60: 640-649.

Sokoloff, L., M. Reivich, C. Kennedy, M. Des Rosiers, C. Patlak, K. Pettigrew, O. Sakurada, and M. Shinohara $(1977){ }^{14} \mathrm{C}$ Deoxyglucose method for the measurement of local cerebral glucose utilization: Theory, procedure and normal values in the conscious and anesthetized albino rat. J. Neurochem. 28: 897-916.

Steel, R. G. D., and J. H. Torrie (1960) Principles and Procedures of Statistics, pp. 99-131, McGraw-Hill Book Co., New York.

Strange, P. G., N. J. M. Birdsall, and A. S. V. Burgen (1977) Occupancy of muscarinic acetylcholine receptors stimulates guanylate cyclase in neuroblastoma cells. Biochem. Soc. Trans. 5: 189-191.

Uchimura, H., J. S. Kim, M. Saito, M. Hirano, M. Ito, and T. Nakahara (1978) Choline acetyltransferase and acetylcholinesterase activities in limbic nuclei of the rat brain. J. Neurochem. 30: 269-272.

Wamsley, J. K., M. A. Zarbin, J. M. Birdsall, and M. J. Kuhar (1980) Muscarinic cholinergic receptors: Autoradiographic localization of high and low affinity agonist sites. Brain Res. 200: $1-12$.

Wamsley, J. K., J. M. Palacios, W. S. Young, and M. J. Kuhar (1981) Autoradiographic determination of neurotransmitter receptor distributions in the cerebral and cerebellar cortices. J. Histochem. Cytochem. 29: 125-135.

Weinberger, J., J. H. Greenberg, M. T. G. Waldman, A. Sylvestro, and M. Reivich (1979) The effect of scopolamine on lucal glucose metabolism in rat brain. Brain Res. 177: 337-345.

White, P., C. R. Hiley, M. J. Goodhardt, L. H. Carrasco, J. P. Keet, I. E. I. Williams, and D. M. Bowden (1977) Neocortical cholinergic neurons in elderly people. Lancet 1: 668-670.

Yamamura, H. I., and S. H. Snyder (1974) Muscarinic cholinergic binding in rat brain. Proc. Natl. Acad. Sci. U. S. A. 71: 1725-1729.

Zeman, W., and R. M. I. Innes (1963) Craigie's Neuroanatomy of the Rat, pp. 137-167, Academic Press, New York. 